\title{
Adenocarcinoma of the Rete Testis a Rare Case of Testicular Malignancy
}

\author{
Adenokarcinóm rete testis - zriedkavý prípad \\ testikulárnej malignity
}

\author{
Chovanec M. ${ }^{1,2}$, Mego M. ${ }^{1,2}$, Sycova-Mila Z. ${ }^{2}$, Obertova J., ${ }^{1,2}$ Rajec J. ${ }^{2}$, Palacka P., ${ }^{1,2}$, Mardiak J., \\ 1 2nd Department of Medical Oncology, Faculty of Medicine, Comenius University, Bratislava, Slovak Republic \\ ${ }^{2}$ National Cancer Institute, Bratislava, Slovak Republic
}

\begin{abstract}
Summary
Background: Adenocarcinoma of rete testis is an extremely rare diagnosis described in around 70 patients worldwide. The prognosis of the disease in metastatic stage is very poor and there is no standard systemic treatment available. Case: Herein we present a unique case report of a 47-year-old man with metastatic adenocarcinoma of rete testis who achieved substantial disease response after four cycles of paclitaxel, ifosfamide and cisplatin. The chemotherapy was administered in five-day regimen, which comprised $250 \mathrm{mg} / \mathrm{m}^{2}$ of paclitaxel on day one, $20 \mathrm{mg} / \mathrm{m}^{2}$ of cisplatin on day one to five and $1,2 \mathrm{~g} / \mathrm{m}^{2}$ of ifosfamide on day one to five, in a three-week interval. The patient received prophylactic pegfilgrastim after each cycle of TIP. The treatment was well tolerated - without any significant toxicity. Result: Patient achieved a partial 14-month remission. Conclusion: On basis of this experience we suggest that paclitaxel, ifosfamide and cisplatin might be adopted as novel agents in treatment of rete testis adenocarcinoma.
\end{abstract}

\section{Key words}

adenocarcinoma - rete testis - chemotherapy - case report - metastatic

\section{Súhrn}

Východiská: Adenokarcinóm rete testis je extrémne vzácna diagnóza popísaná asi u 70 pacientov vo svete. Prognóza ochorenia v metastatickom štádiu je vel'mi zlá a neexistuje štandardná systémová liečba. Popis prípadu: V článku prezentujeme po prvýkrát kazuistiku 47-ročného pacienta s metastatickým adenokarcinómom rete testis, u ktorého sa dosiahla významná odpoved'štyrmi cyklami kombinácie paklitaxelu, ifosfamidu a cisplatiny. Chemoterapia bola podávaná v pät’̉nnovom režime a pozostávala z $250 \mathrm{mg} / \mathrm{m}^{2}$ paklitaxelu v deň prvý, $20 \mathrm{mg} / \mathrm{m}^{2}$ cisplatiny v deň prvý až piaty a $1,2 \mathrm{~g} / \mathrm{m}^{2}$ ifosfamidu deň prvý až piaty, každé tri týždne. Pegfilgrastim bol profylakticky podávaný po každom cykle TIP. Výsledky: Pacient dosiahol parciálnu remisiu trvajúcu 14 mesiacov. Liečba bola tolerovaná dobre bez významnej toxicity. Záver: Na základe tejto skúsenosti sa domnievame, že paklitaxel, ifosfamid a cisplatina môžu byt̉ nové aktívne látky v liečbe adenokarcinómu rete testis.

\section{Klúčová slová}

adenokarcinóm - rete testis - chemoterapia - kazuistika - metastázujúci
This study was supported by grants APVV-0016-11, UK/470/2012.

Práca bola podporená granty APVV-0016-11, UK/470/2012.

The authors declare they have no potential conflicts of interest concerning drugs, products, or services used in the study.

Autoři deklarují, že $v$ souvislosti s predmětem studie nemaji žádné komerční zájmy.

The Editorial Board declares that the manuscript met the ICMJE "uniform requirements" for biomedical papers.

Redakční rada potvrzuje, že rukopis práce splnil ICMJE kritéria pro publikace zasilané do biomedicínských časopisů

doc. MUDr. Michal Mego, Ph.D. 2nd Department of Medical Oncology, Faculty of Medicine, Comenius University

Klenova 1

83310 Bratislava

Slovak Republic

e-mail: misomego@gmail.com 
Adenocarcinoma of rete testis is a rare diagnosis described in around 70 patients worldwide, whereas only 30 patients out of this sample actually meet strict diagnostic criteria [1,2]. This tumor usually occurs in men over 60 years of age but there are a few cases of younger patients described as well $[2,3]$. The prognosis of metastatic disease is very poor and there is no standard treatment strategy defined. Herein we present a unique case report of a 47-year-old man suffering from adenocarcinoma of rete testis who was treated with paclitaxel, ifosfamide and cisplatin with a significant treatment effect.

A 47-year-old man has presented with scrotal enlargement since January 2007. Ultrasonography revealed a tumor mass and left-side orchiectomy was performed in February 2007 extramurally. The patient was not referred to our department until a disease progression was detected. Histologic examination showed a T2 stage adenocarcinoma of rete testis. Genetic analysis detected wild type K-RAS as well as B-RAF alleles. Alpha fetoprotein, $\beta$-human chorionic gonadotropin and serum lactate dehydrogenase were within normal limits, while carcinoembryonic antigen was elevated. Further staging examinations did not prove any metastatic spread of the disease and the patient was indicated for curative surgery. The histological finding of rete testis adenocarcinoma provoked a controversy about surgical method of choice, with hemiscrotectomy being put into question. The patient remained free of disease until
May 2008, when he presented with scrotal pain again and a restaging $C T$ scan uncovered a recurrence in the postoperative scar $(15 \times 16 \mathrm{~mm})$, enlarged retroperitoneal lymph nodes $(21 \times 19 \times 27 \mathrm{~mm})$, as well as multiple metastatic nodules in lungs.

He was treated with four cycles of chemotherapy using paclitaxel, ifosfamide, cisplatin (TIP) until July 2008. Chemotherapy was administered in a five-day regimen, which comprised $250 \mathrm{mg} / \mathrm{m}^{2}$ of paclitaxel on day one, $20 \mathrm{mg} / \mathrm{m}^{2}$ of cisplatin on day one to five and $1,2 \mathrm{~g} / \mathrm{m}^{2}$ of ifosfamide on day one to five. The patient received prophylactic pegfilgrastim after each cycle of TIP. The treatment was well tolerated - without any significant toxicity detected. The patient achieved partial remission according to RECIST criteria in all sites involved. However, in July 2009 he developed disease progression in lungs and the retroperitoneum. Extirpation of enlarged left inguinal lymph nodes proved a metastatic adenocarcinoma compatible with the primary disease. He was commenced on capecitabine and cisplatin chemotherapy and achieved further disease stabilization for more than six months. Subsequently, several courses of palliative chemotherapy were given with only a transient response, followed by disease progression. In May 2011 patient's status deteriorated rapidly and he died of disease progression.

Consistently with a unfavorable prognosis of adenocarcinoma of rete testis, patient's long-term survival was two years and 10 months after the occur- rence of metastases. Apparently, there is a lack of consensus on treatment strategy of this rare tumor. Some authors suggest that the orchiectomy should be followed by retroperitoneal lymph node dissection [4]. There is an evidence of radiotherapy and chemotherapy applied in high-stage tumors without any significant success. There were several chemotherapeutic agents tested for the treatment of adenocarcinoma of rete testis such as methotrexate or 5-flurouracil in monotherapy, or combination therapy based on cisplatin and carboplatin (paclitaxel, cyclophosphamide, 5-fluororacil, dactinomycin, bleomycin, etoposide), all inducing only poor response $[4,5]$. In the light of its resistance, the result of four cycles of TIP establishing disease control for 14 months appears remarkable. This leads us to conclude that paclitaxel with ifosfamide and cisplatin appear promissingin the management of this rare disease. However, further research in this area is warranted.

\section{References}

1. Amin MB. Selected other problematic testicular and paratesticular lesions: rete testis neoplasms and pseudotumors, mesothelial lesions and secondary tumors. Mod Pathol 2005; 18 (Suppl 2): S131-S145.

2. Nochomovitz LE, Orenstein JM. Adenocarcinoma of the rete testis: consolidation and analysis of 31 reported cases with a review of the literature. J Urol Pathol 1994; 2: 1-37. 3. Perimenis P, Athanasopoulos A, Speakman M. Primary adenocarcinoma of the rete testis. Int Urol Nephrol 2003; 35(3): 373-374.

4. Sánchez-Chapado M, Angulo JC, Haas BP. Adenocarcinoma od the rete testis. Urology 1995, 46(4): 468-475.

5. Cullen MH, Stenning SP, Parkinson MC et al. Short-course adjuvant chemotherapy in high-risk stage I nonseminomatous germ cell tumors of the testis: a Medical Research Council report. J Clin Oncol 1996; 14(4): 1106-1113.

\section{Informace z České onkologické společnosti}

Zápis ze schůze výboru České onkologické společnosti konané dne 21. 1. 2014 v Praze naleznete na www.linkos.cz. 